\title{
Isolated large bilateral choroid plexus cysts associated with trisomy 18
}

\author{
Aparna Sharma, Vatsla Dadhwal, Anubhuti Rana, Jaya Chawla
}

Obstetrics and Gynecology, All India Institute of Medical Sciences, New Delhi, Delhi, India

Correspondence to Dr Anubhuti Rana, anubhuti_rana@yahoo.com

Accepted 6 February 2019

\section{DESCRIPTION}

A 20-year-old woman at 18 weeks' period of gestation was referred to the fetal medicine clinic in view of ultrasound (USG) finding of large, irregular, bilateral choroid plexus cysts (CPCs) measuring $16.2 \times 7.9 \mathrm{~mm}$ in the right lateral ventricle and $14.4 \times 7.4 \mathrm{~mm}$ in the left lateral ventricle. She had no prior combined first trimester screening or second trimester biochemical screening. A repeat level II USG at our institution confirmed the finding of large bilateral CPCs with no other structural anomaly or soft markers seen (figure 1). She opted for amniocentesis after genetic counselling in view of the large-sized (>10 mm) bilateral CPCs. Quantitative fluorescence PCR report of amniotic fluid was suggestive of trisomy 18 . She subsequently underwent medical termination of pregnancy (MTP).

CPCs are noted in $\sim 1 \%-2 \%$ of fetuses on USG examinations in the second trimester and are rarely symptomatic. CPCs appear as sonolucent spaces, measuring $2-3 \mathrm{~mm}$ in diameter, in the echogenic choroid plexus of the lateral ventricles of the brain.

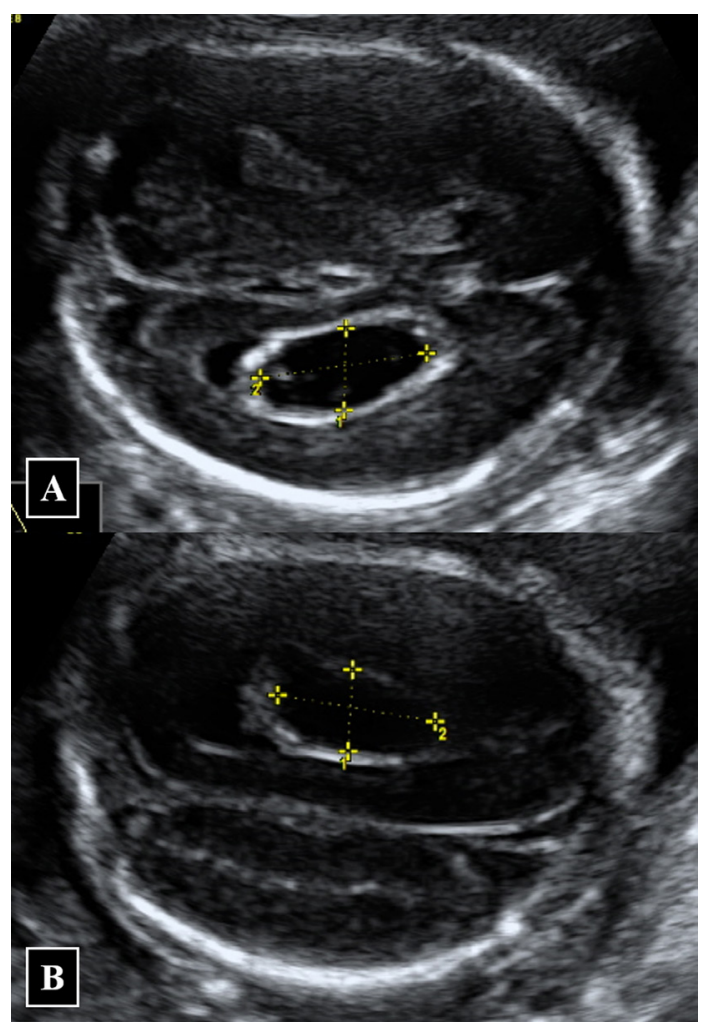

Figure 1 Ultrasound images of the fetal brain (axial plane) shows presence of large choroid plexus cysts measuring $16.2 \times 7.9 \mathrm{~mm}$ in the right lateral ventricle $(A)$ and $14.4 \times 7.4 \mathrm{~mm}$ in the left lateral ventricle (B).
CPCs are seen in about half of the fetuses with trisomy 18 , but only $10 \%$ of fetuses with trisomy 18 will have CPCs as the solitary identifiable indicator on USG. ${ }^{1}$ Even though the number of cysts and the cysts' distribution do not alter the risk, it is seen that cysts with diameters $<5 \mathrm{~mm}$ may not be associated with aneuploidy, while large cysts with diameter $>10 \mathrm{~mm}$ may bear a higher risk of aneuploidy. ${ }^{2}$ A detailed anatomical survey for other markers of trisomy 18, such as cardiac abnormalities, clenched hands, strawberry head, talipes, early fetal growth restriction and polyhydramnios, should be performed in cases of CPCs noted on USG.

By the third trimester, as high as $90 \%$ of CPCs generally disappear, and rarely they persist in the postnatal period. There is no proven neurological injury or any concern with regard to cognitive/ motor behaviour associated with isolated CPC. Hence, the parents need to be counselled and reassured of an excellent prognosis in such cases. The general consensus is that an isolated CPC does not merit follow-up USG, and overall there is no difference in obstetric management in these cases. ${ }^{1}$ However, in this case, even though the CPCs were an isolated finding on USG, on account of the significantly large size of the choroid cysts on either side, invasive prenatal genetic testing was performed and trisomy 18 was detected.

Invasive genetic testing is usually not required in case of an isolated CPC after thorough targeted anomaly USG and biochemical screening for aneuploidy. ${ }^{3}$ In cases of CPC coupled with other anomalies, aneuploidy is expected in $2.1 \%$ of cases and trisomy 18 is more often than not detected in all such cases, making invasive testing necessary in these cases prior to MTP. Due to lower detection rates, non-invasive prenatal testing is not considered the best option in such cases. As previously observed by Sasani et $a l^{2}$ and also highlighted in

\section{Learning points}

Choroid plexus cysts are noted in approximately $1 \%-2 \%$ of fetuses and are rarely clinically significant.

- $10 \%$ of fetuses with trisomy 18 may have choroid plexus cysts as the solitary identifiable indicator on ultrasound.

- While the number of cysts and the cysts' distribution do not alter the risk of aneuploidy, it is seen that large cysts with diameter $>10 \mathrm{~mm}$ may bear a higher risk of aneuploidy and can merit invasive prenatal genetic testing. 
the current case, large CPCs (>10 mm in diameter), although isolated, may be associated with aneuploidy, especially trisomy 18 , and can merit invasive prenatal genetic testing.

Contributors $A S, V D, A R$ and JC have participated sufficiently in the conception of the idea, development of the intellectual content, design, writing and final approval of the manuscript.

Funding The authors have not declared a specific grant for this research from any funding agency in the public, commercial or not-for-profit sectors.

Competing interests None declared.

Patient consent for publication Not required.
Provenance and peer review Not commissioned; externally peer reviewed.

\section{REFERENCES}

1 Van den Hof MC, Wilson RD. Diagnostic Imaging Committee, Society of Obstetricians and Gynaecologists of CanadaGenetics Committee, Society of Obstetricians and Gynaecologists of Canada. Fetal soft markers in obstetric ultrasound. J Obstet Gynaecol Can 2005;27:592-636

2 Sasani M, Afsharian R, Sasani H, et al. A large choroid plexus cyst diagnosed with magnetic resonance imaging in utero: a case report. Cases J 2009;2:7098.

3 Committee on Practice Bulletins-Obstetrics, Committee on Genetics, and the Society for Maternal-Fetal Medicine. Practice Bulletin No. 163: screening for fetal aneuploidy. Obstet Gynecol 2016;127:e123-37.

Copyright 2019 BMJ Publishing Group. All rights reserved. For permission to reuse any of this content visit https://www.bmj.com/company/products-services/rights-and-licensing/permissions/

BMJ Case Report Fellows may re-use this article for personal use and teaching without any further permission.

Become a Fellow of BMJ Case Reports today and you can:

- Submit as many cases as you like

Enjoy fast sympathetic peer review and rapid publication of accepted articles

- Access all the published articles

Re-use any of the published material for personal use and teaching without further permission

For information on Institutional Fellowships contact consortiasales@bmjgroup.com

Visit casereports.bmj.com for more articles like this and to become a Fellow 